\title{
Assessment of serum lactate levels, blood glucose values and blood gas values in sheep, newborn lambs and placenta
}

\author{
Leticia Peternelli Silva ${ }^{2 *}$, Maria L.G. Lourenço ${ }^{3}$, Renata A. Paula ${ }^{3}$, \\ Mirela R. Verdugo ${ }^{3}$, Keylla H.N.P. Pereira ${ }^{3}$ and Simone B. Chiacchio ${ }^{3}$
}

\begin{abstract}
Peternelli Silva L., Lourenço M.L.G., Paula R.A., Verdugo M.R., Pereira K.H.N.P. \& Chiacchio S.B. 2018. Assessment of serum lactate levels, blood glucose values and blood gas values in sheep, newborn lambs and placenta. Pesquisa Veterinária Brasileira 38(9):1878-1884. Faculdade de Medicina Veterinária e Zootecnia, Universidade Estadual Paulista, Departamento de Clínica Veterinária, Rua Prof. Dr. Walter Mauricio Correa s/n, Distrito de Rubião Júnior, Botucatu, SP 18618-681 Brazil. E-mail: mege@fmvz.unesp.br

Newborn animals, in the fetal-to-neonatal transition, usually face several challenges in their first 24 hours, including issues with acid-base balance, glycemic levels and oxygenation. Difficulties to overcome such issues have caused several deaths among newborns. Therefore, studies have been carried out in order to evaluate them. The main purpose of this study is to evaluate the correlation between the serum lactate level in the mother, in the placenta and in the newborn. Moreover, the study measured the lactate level, blood glucose level and blood gas level in the first 24 hours. Tests were carried out right after birth, and at $4,8,12$ and 24 hours after. Lactate levels were quite similar to the placental levels ( $p=0.991)$ which, in turn, were significantly different from the mother's ( $p=0.011)$. Results showed that, shortly after birth, the production of lactate in the placenta is part of the issue. Along the first 24 hours, the study observed a reduction of the levels of lactate in newborns; the levels were closer to the normal index levels for the species. Regarding the blood gas test results, we observed mild metabolic acidosis at birth; acid-base balance was completely stable at the end of the period.
\end{abstract}

INDEX TERMS: Serum lactate, blood glucose, blood gas, sheep, newborn, lambs, placenta, ewes, lactate, physiology.

RESUMO.- [Avaliação da concentração de lactato sérico, glicemia e hemogasometria de ovelhas, cordeiros recém-nascidos e placenta.] Os principais desafios da transição fetal-neonatal são a estabilização do equilíbrio ácido-básico, glicemia e oxigenação ao longo das primeiras 24 horas de vida. Falhas nesse sistema são a maior causa de morte nesse período e os estudos de viabilidade neonatal tem se concentrado nas avaliações destas variáveis. 0 objetivo do presente estudo foi avaliar a comparação da lactatemia materna,

\footnotetext{
${ }^{1}$ Received on January 20, 2018.

Accepted for publication on March 26, 2018.

${ }^{2}$ Universidade de Marília, Faculdade de Medicina Veterinária, Associação de Ensino de Marília, Mirante Marília, SP 17525-902, Brazil.

${ }^{3}$ Faculdade de Medicina Veterinária e Zootecnia, Universidade Estadual Paulista (Unesp), Departamento de Clínica Veterinária, Rua Prof. Dr. Walter Mauricio Correa s/n, Distrito de Rubião Júnior, Botucatu, SP 18618-681 Brazil. *Corresponding author: mege@fmvz.unesp.br
}

placentária e neonatal ao nascimento e, ainda, observar o comportamento do lactato, glicemia e hemogasometria nas primeiras 24 horas de vida do neonato ovino. Para tanto, as avaliações foram realizadas ao nascimento, 4, 8, 12 e 24 horas após. A lactatemia neonatal se mostrou próxima à placentária $(\mathrm{p}=0,991)$ e significativamente diferente da materna $(\mathrm{p}=0,011)$, o que sugere uma influência da produção de lactato pela placenta na lactatemia neonatal ao nascimento. Ao longo das 24 horas de vida foi possível observar a depuração de lactato pelo organismo do neonato, aproximando assim dos valores de referência para a espécie. Na hemogasometria foi possível observar discreta acidose metabólica, com normalização já nas primeiras 4 horas e estabilização completa do equilíbrio ácido-básico ao final das 24 horas de vida.

TERMOS DE INDEXAÇÃO: Lactato sérico, glicemia, hemogasometria, ovelhas, cordeiros, recém-nascido, placenta, ovinos, lactato, fisiologia. 


\section{INTRODUCTION}

Adaptation to life outside the womb, also known as fetal-to-neonatal transition, is a complex biological process involving functional modifications in all organs and systems of the newborn, allowing survival after separation from the mother's uterus and placenta. The key aspects of this transition are: pulmonary expansion for gas exchanges, establishment of an adult-like and stable circulation; maintenance of the newborn's body temperature and metabolic adaptation to life outside the uterus (Teixeira et al. 2007).

Glucose is the main energy substrate in the fetal and placental metabolism in all mammalian species (Brolio et al. 2010). Anaerobic glycolysis is a process that uses glucose to produce lactate in the absence of oxygen (Barroso et al. 2006). The glucose requirement of the fetus-placenta unit may represent up to $70 \%$ of the overall glucose metabolism in pregnant ewes, most of which is used by the placenta. The remaining glucose is used by the fetus, which has only $46 \%$ of its energy needs supplied by glucose, with amino acid catabolism representing 25\%, lactate representing 20\% and a small fraction from alanine (Brolio et al. 2010). During the fetal stage, lactate plays a role in oxidation, fatty acid synthesis and glycogen synthesis (Gleason et al. 1985). Lactate plays a key role in both human and veterinary obstetrics as a marker for fetal and neonatal distress (Armstrong et al. 2006) and is one of the main elements of metabolic acidosis (Borruto et al. 2008).

Uterine contractions and the rupture of the fetal membranes during natural birth cause alterations in the uterine and placental blood circulation, promoting a mild and temporary mixed acidosis, which is considered physiologic with blood $\mathrm{pH}$ around 7.2 (Ravary-Plumioen 2009). During the pregnancy and birth, the animal is subjected to a low oxygen supply. Healthy neonates suffer from mild cases of acidosis while animals born from complicated births invariably present lower blood pH levels (Gardiner 1980). This happens after the umbilical cord is broken, due to the anaerobic glycolysis that happens in low-circulation tissue during the transition between placental oxygen supply and the establishment of the respiratory function (Vaala \& House 2006). This condition is aggravated by the limited respiratory capacity of a neonate, characterized by a hypoventilation which does not guarantee the removal of all carbon dioxide (CO2) produced. This results in a buildup of carbon dioxide, which leads to the production of carbonic acid and, therefore, a decrease in the blood $\mathrm{pH}$ levels (Piccione et al. 2006).

The use of a portable clinical analyzer allows the assessment of chemical and electrolytical parameters, as well as $\mathrm{pH}$ and gas levels, in venous blood samples. This equipment has been validated in human medicine (Dascombe et al. 2007) and has also been employed recently with reliable results in veterinary medicine (Silverman \& Birks 2002, Veronesi et al. 2014).

The main purpose of this study was to evaluate the correlation between the serum lactate levels in the mother, in the placenta and in the newborn, identifying one of the causes of neonatal physiological hyperlactatemia and its correlation with placental production, also measuring the lactate levels, blood glucose levels and blood gas levels in the first 24 hours.

\section{MATERIALS AND METHODS}

Ethics statement. The experiment was conducted at Cabanha Unimar, located inside Experimental Farm "Marcelo Mesquita Serva" (University of Marília - Unimar) in the city of Marília, São Paulo, Brazil at latitude $22^{\circ} 12^{\prime} 50^{\prime \prime} \mathrm{S}$, longitude $49^{\circ} 56^{\prime} 45^{\prime \prime} \mathrm{W}$. The study was approved by the Commission for Ethics in the Use of Animals of the College of Veterinary Medicine and Animal Sciences, São Paulo State University, Botucatu, Brazil, under protocol no. 194/2013.

Animals used. We used 14 crossbred ewes and their respective lambs, including nine females and eight males, among which there were six twins. After confirming the pregnancy, the ewes were separated in a rotational grazing system and then duly vaccinated and vermifuged. Upon the end of pregnancy, the ewes were taken to a smaller enclosure where the first assessments were conducted during the lambs' first day of life. Two other ewes with labor dystocia of fetal origin were excluded from the study. The lambs remained with the mothers throughout the evaluation period. No deaths happened during the assessed period.

Sample collection. Blood was collected from neonates and mothers through jugular venipuncture after the first contact between mother and lamb. Blood samples were also collected from the neonates four, eight, twelve and twenty-four hours after birth. Total placental blood samples were collected immediately after birth, before placental expulsion, through puncture of the venous intercotyledonary vessels described by (Schoenau et al. 2005).

Assessment lactate. A single drop of total blood was used for direct assessment of the levels of lactate immediately after collection through a portable analyzer (Accutrend ${ }^{\circledR}$, Roche Diagnostic Corporation, Indianapolis, IN, USA).

Assessment blood glucose. To measure the blood glucose levels, the samples were assessed immediately after collection using a portable glucose meter (Accu-chek Active ${ }^{\circledR}$, Roche Diagnostic Corporation, Indianapolis, IN, USA).

Assessment blood gas levels. To determine blood gas levels, the blood samples from the lambs were collected through jugular venipuncture in syringes prepared previously with sodium heparin (1000 UI/mL) immediately after birth and then four, eight, twelve and twenty-four hours after birth. The blood gas assays were conducted using a portable clinical analyzer (i-Stat ${ }^{\circledR}$ Portable Clinical Analyzer, Abbott Laboratories, Abbott Park, Illinois, USA) with specific cartridges (EG7+ ${ }^{+}$, Abbott Laboratories, Abbott Park, Illinois, USA) according to the manufacturer's recommendations. The following parameters were determined: sodium $\left(\mathrm{Na}^{+} ; \mathrm{mEq} / \mathrm{L}\right)$, potassium $\left(\mathrm{K}^{+} ; \mathrm{mEq} / \mathrm{L}\right)$, ionized calcium (iCa; $\left.\mathrm{mM}\right)$, bicarbonate $\left(\mathrm{HCO}_{3}^{-}\right)$, potential of hydrogen $(\mathrm{pH})$, oxygen saturation $\left(\mathrm{sO}_{2}\right)$, carbon dioxide $\left(\mathrm{TCO}_{2} ; \mathrm{mM}\right)$, carbon dioxide partial pressure $\left(\mathrm{PCO}_{2} ; \mathrm{mmHg}\right)$, oxygen partial pressure $\left(\mathrm{PO}_{2} ; \mathrm{mmHg}\right)$, base excess/deficit (BEecf; $\mathrm{mM}$ ), hematocrits ( $\mathrm{Ht} ; \%)$ and hemoglobin ( $\mathrm{Hb})$. The values for $\mathrm{pH}, \mathrm{PO}_{2}$ and $\mathrm{PCO}_{2}$ were corrected according to each animal's rectal temperature, since this can influence these parameters and, consequently, the hemoglobin dissociation curve.

Statistical analysis. The distribution of all variables were assessed through graphs and normality tests (Kolmogorov-Smirnov) across the studied moments. For the assessment of the variables obtained from lambs, we employed variance analysis for repeated measurements, Friedman's non-parametric test followed by Dunn's post hoc test to determine the median for each variable at the studied moments. To analyze the lactate and blood glucose levels among the groups, we employed Kruskal-Wallis' non-parametric 
test followed by Dunn's test. All analyses were conducted using the software Graphpad Prism 5.0 (GraphPad Software ${ }^{\circledR}$, La Jolla, San Diego, CA, USA). P values inferior to 0.05 were considered statistically significant.

\section{RESULTS}

Neonatal lactatemia at the time of birth has proved to be very close to the placental values and we observed lactate clearance during the following analyses (Tables 1 and 2). We observed statistical differences when comparing mother versus placenta $(\mathrm{p}<0.015)$ and mother versus neonate $(\mathrm{p}<0.015)$ at the time of birth and four hours after birth $(p<0.032)$. There were no statistical differences in the values obtained eight, twelve and twenty-four hours after birth or in the comparison between neonate and placenta in any of the studied moments (Fig.1).

Lactate clearance in the neonate's organism happened gradually during the first 24 hours, evidenced in the comparing the results obtained at the time of birth with the one obtained after 24 hours $(\mathrm{p}=0.0065)$ and the results obtained after 4 hours with the ones obtained after 24 hours $(p=0.0065)$. These differences were not observed when comparing the other moments studied (Table 2 and Fig.2).

Neonatal blood glucose levels have differed significantly compared to that in mother $(\mathrm{p}=0.001)$ at the time of birth at around 60 to $70 \%$ (Table 3 and Fig.3). We also observed a gradual increase in the serum values during the neonate's first 24 hours (Table 3 and Fig.4), with significant differences between birth and the other moments studied: birth versus 4 hours $(\mathrm{p}=0.001)$, birth versus 8 hours $(\mathrm{p}=0.001)$, birth versus 12 hours $(p=0.001)$ and birth versus 24 hours $(\mathrm{p}=0.001)$.

The variables analyzed in hemogasometry are presented in table 4. Among them the $\mathrm{pH}$ showed a significant increase from birth to 4 hours after $(\mathrm{p}<0.01)$ and from birth to 24 hours after $(\mathrm{p}<0.01)$. No significant differences were observed in the comparison between the other moments studied. Still can be observed an acid-base alteration, with

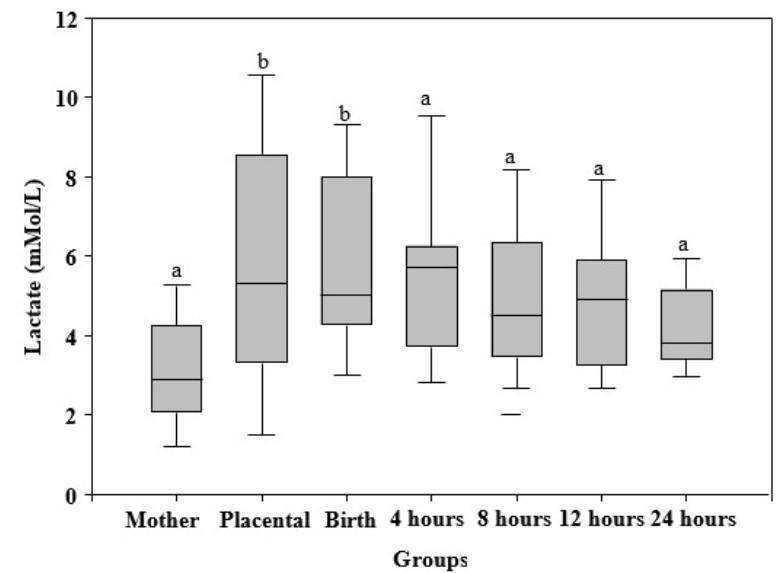

Fig.1. Serum lactate concentration in the groups assessed. Different letters $(a, b, c)$ indicate a statistical difference $(\mathrm{p}<0.05)$ between groups.

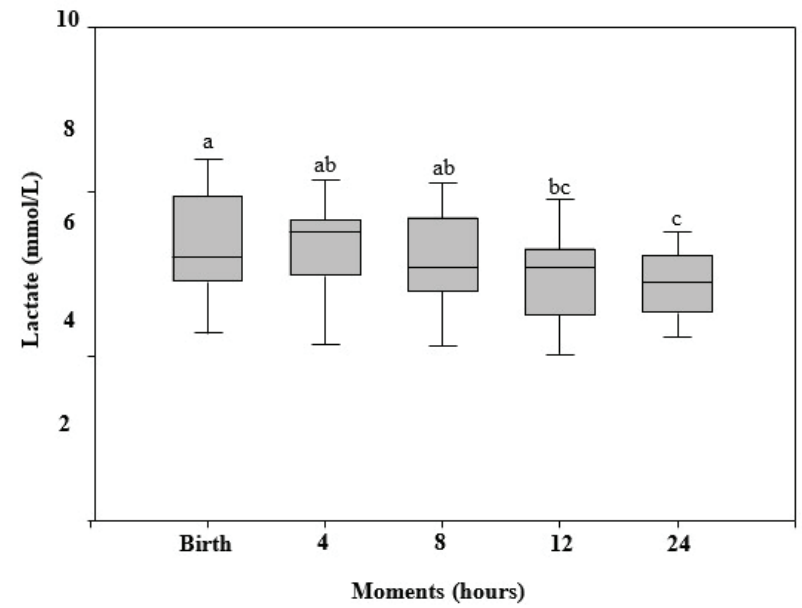

Fig.2. Serum lactate concentration in neonate lambs at the time of birth and 4, 8, 12 and 24 hours after. Different letters (a,b, c) indicate a statistical difference $(\mathrm{p}<0.05)$ between moments.

Table 1. Serum lactate concentration in the mothers, placenta and lambs at the time of birth and after 4, 8, 12 and 24 hours

\begin{tabular}{|c|c|c|c|c|}
\hline & Ewes & Placenta & Neonates & \\
\hline \multirow[t]{5}{*}{ Lactate } & $3.092 \pm 1.391^{\mathrm{a}}$ & $5.777 \pm 3.032^{\mathrm{b}}$ & $5.892 \pm 2.211^{\mathrm{b}}$ & Birth \\
\hline & & & $5.477 \pm 2.188^{\mathrm{b}}$ & 4 hours \\
\hline & & & $4.992 \pm 1.854^{\mathrm{ab}}$ & 8 hours \\
\hline & & & $4.831 \pm 1.759^{a b}$ & 12 hours \\
\hline & & $3.800 \pm 3.450 \mathrm{ab}$ & 24 hours & \\
\hline
\end{tabular}

$\overline{a, b, c}$ Different letters indicates a significant difference $(p<0.05)$ within moments.

Table 2. Serum lactate concentration in neonate lambs at the time of birth and after 4, 8, 12 and 24 hours

\begin{tabular}{|c|c|c|c|c|}
\hline & \multicolumn{4}{|c|}{ Lactate $(\mathrm{mMol} / \mathrm{L})$} \\
\hline & Average \pm DP & Minimum & Maximum & Reference \\
\hline Birth & $5.671 \pm 1.995^{a}$ & 2.9 & 9.6 & $<4$ \\
\hline 4 hours & $5.618 \pm 1.939^{a b}$ & 2.7 & 11.1 & (Comline \& Silver 1971) \\
\hline 8 hours & $5.118 \pm 1.700^{\mathrm{ab}}$ & 2.5 & 8.5 & \\
\hline 12 hours & $4.718 \pm 1.559^{\mathrm{bc}}$ & 2.6 & 8.7 & \\
\hline 24 hours & $4.282 \pm 0.9322^{c}$ & 2.9 & 6 & \\
\hline
\end{tabular}

a, b, c Different letters indicates a significant difference $(\mathrm{p}<0.05)$ within moments. 
mild primary metabolic acidosis expressed by a small decrease in the $\mathrm{BE}$ and $\mathrm{HCO}_{3}$ values at birth, as well as a mild compensatory respiratory alkalosis highlighted by the reduction in the $\mathrm{PCO}_{2}$ values. The total concentration of carbon dioxide $\left(\mathrm{TCO}_{2} \mathrm{mmol} / \mathrm{L}\right)$ increased during the evaluated moments, especially in the comparison between birth and 24 hours $(p<0.001)$, four and 24 hours $(p<0.001)$ and eight and 24 hours $(\mathrm{p}<0.001)$. Among the electrolytes, serum sodium concentration dropped significantly between eight and 24 hours after birth $(\mathrm{p}<0.005)$. Such significance difference was not observed in the other moments studied. There was a decrease in the concentration of potassium, but without significant.

The globular volume decreased during the first 24 hours of the neonate's life, there was a significant difference between birth and 12 hours $(\mathrm{p}<0.005)$, birth and 24 hours $(\mathrm{p}<0.001)$ and 8 and 24 hours $(p<0.01)$. Hemoglobin concentration decreased significantly when we compared the same times (Table 4), birth versus 12 hours ( $\mathrm{p}<0.005$ ), birth and 24 hours $(p<0.001)$ and 8 versus 24 hours $(p<0.01)$.

Table 3. Maternal, placental and neonatal lambs blood glucose at birth and after 4, 8, 12 and 24 hours

\begin{tabular}{|c|c|c|c|c|}
\hline & Ewes & Placenta & & \\
\hline \multirow[t]{5}{*}{ Glucose } & $131,727 \pm 38,936^{a}$ & $33,364 \pm 32,346^{\mathrm{b}}$ & $47,545 \pm 23,390^{b}$ & Birth \\
\hline & & & $107,091 \pm 46,773^{a}$ & 4 hours \\
\hline & & & $118,545 \pm 75,717^{a}$ & 8 hours \\
\hline & & & $110,000 \pm 42,953^{a}$ & 12 hours \\
\hline & & $102,273 \pm 21,546^{\mathrm{a}}$ & 24 hours & \\
\hline
\end{tabular}

a,b,c Different letters indicates significant difference $(\mathrm{p}<0.05)$ within moments.

Table 4. Blood gas variables studied at the time of birth and after 4, 8, 12 and 24 hours

\begin{tabular}{|c|c|c|c|c|c|c|}
\hline Variable & Birth & 4 hours & 8 hours & 12 hours & 24 hours & Reference \\
\hline $\mathrm{pH}$ & $7.381 \pm 0.07051^{\mathrm{a}}$ & $7.494 \pm 0.1641^{\mathrm{bc}}$ & $7.452 \pm 0.06269^{\mathrm{ab}}$ & $7.456 \pm 0.08879^{\mathrm{ab}}$ & $7.501 \pm 0.07628^{b}$ & $\begin{array}{c}7.33 \pm 0.04 \\
\text { (Vannucchi et al. 2012) }\end{array}$ \\
\hline $\begin{array}{c}\mathrm{BE} \\
(\mathrm{mEq} / \mathrm{L})\end{array}$ & $-4.294 \pm 3.965^{\mathrm{a}}$ & $-1.176 \pm 4.461^{\mathrm{ab}}$ & $-1.471 \pm 3.044^{\mathrm{ab}}$ & $0.235 \pm 4.280^{\mathrm{bc}}$ & $4.118 \pm 4.781^{c}$ & $\begin{array}{l}-4 \text { a } 4 \\
\text { (Rodrigues et al. 2007) }\end{array}$ \\
\hline $\begin{array}{l}\text { Bicarbonate } \\
(\mathrm{mEq} / \mathrm{L})\end{array}$ & $20.759 \pm 3.477^{a}$ & $22.171 \pm 2.708^{\mathrm{ab}}$ & $22.494 \pm 2.588^{\mathrm{ab}}$ & $24.135 \pm 3.504^{\mathrm{bc}}$ & $27.247 \pm 3.904^{c}$ & $\begin{array}{c}23.88 \pm 2.17 \\
\text { (Vannucchi et al. 2012) }\end{array}$ \\
\hline $\begin{array}{c}\mathrm{PCO}_{2} \\
(\mathrm{mmHg})\end{array}$ & $35.235 \pm 7.340$ & $30.141 \pm 9.051$ & $32.406 \pm 5.569$ & $34.541 \pm 6.556$ & $34.794 \pm 4.416$ & $\begin{array}{c}45.2 \pm 4.7 \\
\text { (Vannucchi et al. 2012) }\end{array}$ \\
\hline $\begin{array}{c}\mathrm{PO}_{2} \\
(\mathrm{mmHg})\end{array}$ & $100.47 \pm 54.980$ & $108.06 \pm 51.492$ & $84.765 \pm 56.148$ & $65.059 \pm 40.512$ & $61.235 \pm 38.276$ & $\begin{array}{c}46.0 \pm 11.8 \\
\text { (Vannucchi et al. 2012) }\end{array}$ \\
\hline $\begin{array}{c}\mathrm{TCO}_{2} \\
(\mathrm{mEq} / \mathrm{L})\end{array}$ & $22.000 \pm 3.571^{\mathrm{a}}$ & $23.059 \pm 2.727^{\mathrm{a}}$ & $23.471 \pm 2.625^{\mathrm{a}}$ & $25.000 \pm 3.518^{\mathrm{ab}}$ & $28.294 \pm 3.837^{\mathrm{b}}$ & $\begin{array}{c}24.0 \pm 1.98 \\
\text { (Vannucchi et al. 2012) }\end{array}$ \\
\hline $\begin{array}{l}\mathrm{SO}_{2} \\
(\%)\end{array}$ & $91.706 \pm 9.828$ & $90.412 \pm 16.767$ & $86.059 \pm 15.332$ & $81.706 \pm 17.581$ & $80.647 \pm 18.695$ & $\begin{array}{c}59.83 \pm 10.85 \\
(\text { Feitosa et al. 2011) }\end{array}$ \\
\hline $\begin{array}{c}\mathrm{Na} \\
(\mathrm{mEq} / \mathrm{L})\end{array}$ & $145.000 \pm 2.669^{\mathrm{ab}}$ & $146.000 \pm 2.550^{\mathrm{ab}}$ & $146.588 \pm 2.265^{\mathrm{a}}$ & $146.471 \pm 2.918^{\mathrm{ab}}$ & $144.765 \pm 2.658^{b}$ & $\begin{array}{c}147.5 \pm 1.51 \\
\text { (Vannucchi et al. 2012) }\end{array}$ \\
\hline $\begin{array}{c}\mathrm{K} \\
(\mathrm{mEq} / \mathrm{L})\end{array}$ & $4.465 \pm 0.335$ & $4.665 \pm 0.841$ & $4.594 \pm 0.715$ & $4.688 \pm 0.681$ & $4.735 \pm 0.552$ & $\begin{array}{c}4.2 \pm 0.61 \\
\text { (Vannucchi et al. 2012) }\end{array}$ \\
\hline $\begin{array}{l}\mathrm{VG} \\
(\%)\end{array}$ & $38.000 \pm 5.025^{\mathrm{a}}$ & $36.588 \pm 3.890^{\mathrm{abc}}$ & $36.235 \pm 4.521^{\mathrm{ab}}$ & $35.647 \pm 3.904^{\mathrm{bc}}$ & $34.176 \pm 3.957^{c}$ & $\begin{array}{c}33.72 \pm 0.6 \\
\text { (Gama et al. 2007) }\end{array}$ \\
\hline $\begin{array}{c}\mathrm{Hb} \\
(\mathrm{g} / \mathrm{dL})\end{array}$ & $12.906 \pm 1.702^{\mathrm{a}}$ & $12.441 \pm 1.337^{\mathrm{abc}}$ & $12.324 \pm 1.535^{\mathrm{ab}}$ & $12.118 \pm 1.334^{\mathrm{bc}}$ & $11.618 \pm 1.334^{\mathrm{c}}$ & $\begin{array}{c}12.9 \\
\text { (Gama et al. 2007) }\end{array}$ \\
\hline
\end{tabular}

a,b,c Different letters indicates a significant difference $(p<0.05)$ within moments. 


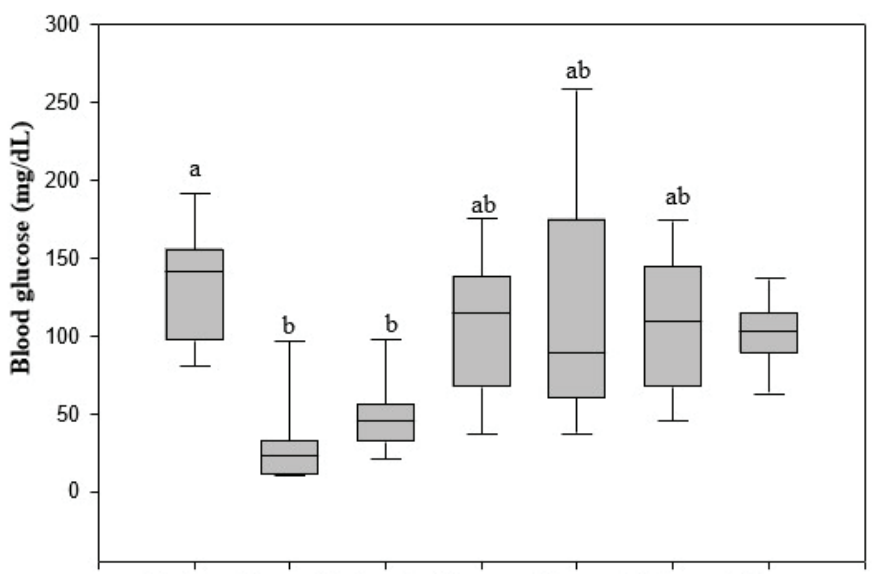

Mother Placental Birth 4 hours 8 hours 12 hours 24 hours

\section{Groups}

Fig.3. Blood glucose levels in the groups assessed. Different letters $(a, b, c)$ indicate a statistical difference $(p<0.05)$ between the groups.

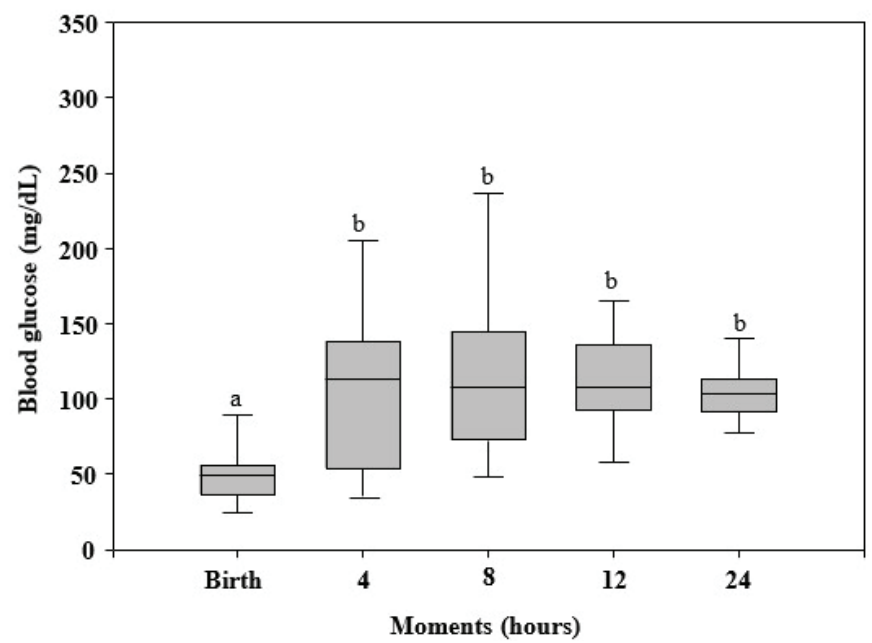

Fig.4. Blood glucose levels in neonate lambs at the time of birth and 4, 8, 12 and 24 hours after. Different letters $(a, b, c)$ indicate a statistical difference $(p<0.05)$ between moments.

\section{DISCUSSION}

Neonatal hyperlactatemia has been shown to be physiological in several studies (Comline \& Silver 1972, Peternelli Silva 2012, Silva 2012, Silva et al. 2013, Regazzi 2015). In this study, it was demonstrated the production of lactate in the placenta and its distribution to the fetus, as shown by Sparks et al. (1983). There are no studies in the literature assessing the interference of placental lactatemia over the initial neonatal lactatemia and this study is the first in the field of ovine neonatology. However, more studies regarding this interference are needed as it may be used to determine when the neonatal hyperlactemia stops being physiological, a possible prognostic factor during neonatal assessment.

Lactate clearance by the neonate's body occurred gradually in the first 24 hours, this was due to pulmonary and metabolic stabilization and maturation (Ronco 2005). This reduction in lactatemia was also observed by Silva (2012) in ovine and by Castagnetti et al. (2010) and Cruz (2014) in equidae.

Neonatal blood glucose levels have differed statistically from the mother's, as described by Andrade (2002) in humans. Neonate blood glucose levels were also above the normality standards established by Vannucchi et al. (2012) and Peternelli Silva (2012) and below the levels observed by Regazzi (2015). As happened with lactate, this variable has been shown to be closer to the values obtained from the placenta at the time of birth and has diverged statistically after a second assessment four hours after birth $(p=0.001)$. The gradual increase in the serum values blood glucose during the neonate's first 24 hours is due to the ingestion of colostrum, the increase in glucose absorption and the stimulation of gluconeogenesis (Josefson \& Zimmerman 2009).

During pregnancy and birth, the animal is subjected to a low supply of oxygen. Healthy neonates suffer from mild acidosis while animals born from complicated births invariably present significantly lower blood $\mathrm{pH}$ values (Bovino 2011). The physiological values are maintained through the establishment of intracellular and extracellular buffering processes associated to the physiological regulatory processes in the lungs and kidneys (Andrade \& Hirschhheimer 2005). Despite a statistically significant increase between birth and the first 24 hours of life $(\mathrm{p}<0.01)$, the $\mathrm{pH}$ levels have remained inside the normality standards the entire time, something that was also observed by Silva (2012) and Bovino (2011). On the other hand, Vannucchi et al. (2012) observed acidemia in premature ovine neonates due to an alteration in the $\mathrm{pH}$ levels. The maintenance of $\mathrm{pH}$ levels happen due to compensation through the reduction in the $\mathrm{PCO}_{2}$ levels that happen with hyperventilation and, therefore, we did not observe acidemia (Bailey \& Pablo 1998).

In this study, we observed an acid-base alteration, with mild primary metabolic acidosis expressed by a small decrease in the $\mathrm{BE}$ and $\mathrm{HCO}_{3}$ values at birth, as well as a mild compensatory respiratory alkalosis highlighted by the reduction in the $\mathrm{PCO}_{2}$ values. These alterations have not been maintained in the following analyses, which indicate an adequation of the acid-base balance. Regazzi (2015) has also observed these patterns in ovines. Silva (2012) and Vannucchi et al. (2012) have also observed a decrease in the levels of $\mathrm{HCO}_{3}$, but with hypercapnia in the studied ovine neonates.

The metabolization of oxygen in the tissues result in the formation of $\mathrm{CO}_{2}$ molecules and then $\mathrm{HCO}_{3}$ and $\mathrm{H}+$ molecules, which contribute to the increases observed in these indexes (Regazzi 2015). We also observed a statistically significant increase in the levels of $\mathrm{TCO}_{2}$, but within the normality standards at all studied moments. This was also observed by Regazzi (2015) in ovine neonates born from eutocic births.

Under acidosis, $\mathrm{H}+$ ions are scrambled with the intracellular sodium and potassium ions, increasing their blood concentrations. In this study, we observed a significant reduction in the serum concentration of sodium during the neonate's first 24 hours $(p<0.005)$, indicating the stabilization of the acid-base balance within this time frame. However, the values obtained remained within the standards established by Vannucchi et al. (2012). On the other hand, Silva (2012) observed hyponatremia in premature lambs within all groups studied while Rocha et al. (2009) observed it in bovines at the time of birth. 
Studies conducted in young ovines have shown that the number of red cells, corpuscular volume and hemoglobin concentration decrease during the first month of life as part of the physiological dynamics (Gama etal. 2007). In this study, the corpuscular volume has decreased during the neonate's first 24 hours ( $p<0.001)$, followed by hemoglobin, something which was also observed by Gama et al. (2007) and Regazzi (2015) in lambs during the same time frame. However, the values observed at the time of birth in this study were above those observed by Gama et al. (2007), Lima et al. (2015) and Regazzi (2015).

\section{CONCLUSIONS}

The concentration of lactate in neonate lambs presents a physiological increase at the time of birth. Lactate clearance happens during the neonate's first 24 hours, getting closer to the reference values for the species.

Neonatal lactatemia at the time of birth is influenced by the placental production of lactate.

The neonate is born with a mild metabolic acidosis, which is normalized during the first 24 hours with the stabilization of the acid-base balance.

\section{REFERENCES}

Andrade O.V.B. \& Hirschhheimer M.R. 2005. Gasometria arterial, p.369-376. In: Carvalho W.B., Hirschheimer M.R., Proença Filho J.O., Freddi N.A. \& Troster E.J. (Eds), Ventilação Pulmonar Mecânica em Pediatria e Neonatologia. $2^{\underline{a}}$ ed. Atheneu, São Paulo.

Andrade S.M.A. 2002. Glicemia Neonatal: comparação dos resultados da determinação da glicemia em recém-nascidos através de amostra sérica venosa e amostra de sangue capilar. Dissertação de Mestrado, Universidade Federal do Rio Grande do Sul, Porto Alegre. 91p.

Armstrong L., Stenson B., Blickstein I. \& Green T. 2006. Effect of delayed sampling on umbilical cord arterial and venous lactate and blood gases in clamped and unclamped vessels. Arch. Dis. Child. Fetal Neonat. 91(5):342345. <http://dx.doi.org/10.1136/adc.2005.086744><PMid:16638782>

Bailey J.E. \& Pablo L.S. 1998. Practical approach to acid-base disorders. Vet. Clin. N. Am., Small Anim. Pract. 28(3):645-662.<http://dx.doi.org/10.1016/ S0195-5616(98)50060-5><PMid:9597719>

Barroso R.M.V., Gallego J.G., Talhate J., Denicolli L., Ideriha N.M., Rabelo R., Bertolini M.M. \& Sarmento P. 2006. A utilização do lactato como marcador biológico prognóstico. UNESC Rev. 9:157-172.

Borruto F., Comparetto C. \& Treisser A. 2008. Prevention of cerebral palsy during labour: role of foetal lactate. Arch. Gynecol. Obstet. 278(1):17-22. <http://dx.doi.org/10.1007/s00404-007-0531-1> <PMid:18071726>

Bovino F. 2011. Determinação do escore apgar, dos valores hemogasométricos e do proteinograma sérico de cordeiros (Ovis aries) nascidos de partos normais e de cesarianas. Dissertação de Mestrado em Ciência Animal, Universidade Estadual Paulista, Araçatuba. 85p.

Brolio M.P., Ambrósio C.E., Franciolli A.R., Morini A.C., Guerra R.R. \& Miglino M.A. 2010. A barreira placentária e sua função de transferência nutricional. Revta Bras. Reprod. Anim. 34:222-232.

Castagnetti C., Pirrone A., Mariella J. \& Mari G. 2010. Venous blood lactate evaluation in equine neonatal intensive care. Theriogenology 73(3):343357. <http://dx.doi.org/10.1016/j.theriogenology.2009.09.018> <PMid:19962183>

Comline R.S. \& Silver M. 1971. Catecholamine secretion by the adrenal medula of the foetal and newborn foal. J. Physiol. 216(3):659-682. PMID: 5565643.
Comline R.S. \& Silver M. 1972. The compositon of foetal and maternal blood during parturition in the ewe. J. Physiol. 222(1):233-256. <http://dx.doi. org/10.1113/jphysiol.1972.sp009795><PMid:5037074>

Cruz R.K.S. 2014. Avaliação dos padrões de vitalidade neonatal, hemogasometria e eletrocardiografia em equinos da raça Pain Horse. Dissertação de Mestrado, Universidade Estadual Paulista, Botucatu. 103p.

Dascombe B.J., Reaburn P.R.J., Sirotic A.C. \& Coutts A.J. 2007. The reliability of the i-STAT clinical portable analyser. J. Sci. Med. Sport. 10(3):135-140. <http://dx.doi.org/10.1016/j.jsams.2006.05.023> <PMid:16846754>

Feitosa F.L.F., Perri S.H.V., Bovino F., Mendes L.C.N., Peiró J.P., Gasparelli E.R. \& Camargo D.G. 2011. Avaliação da vitalidade de bezerros nelores nascidos de partos normais ou distócicos. Ars Vet. 27(3):1-7.

Gama S.M.S., Matos J.R., Zacharias F., Chaves Filho R.M., Guimarães J.E., Bittencourt T.C.B.S.C. \& Ayres M.C.C. 2007. Dinâmica do eritrograma de cordeiros, resultantes do cruzamento entre animais de raças nativas criadas no Nordeste e a raça Dorper, desde o nascimento até os seis meses de idade. Revta Bras. Saúde Prod. Anim. 8:11-23.

Gardiner R. 1980. Cerebral blood flow and oxidative metabolism during hypoxia and asphyxia in the newborn calf and lamb. J. Physiol. 305(1):357-376. <http://dx.doi.org/10.1113/jphysiol.1980.sp013369><PMid:6777488>

Gleason C.A., Rudolph C., Bristow J., Itskowitz J. \& Rudolph A.M. 1985. Lactate uptake by the fetal and neonatal sheep liver. Pediatr. Res. 19:155-155A.

Josefson J. \& Zimmerman D. 2009. Hypoglicemia in the emergency. Clin. Pediatr. Emerg. Med. 10(4):285-291. <http://dx.doi.org/10.1016/j. cpem.2009.10.008>

Lima M.B., Monteiro M.V.B., Jorge E.M., Campello C.C., Rodrigues L.F.S., Viana R.B., Monteiro F.O.B. \& Costa C.T.C. 2015. Blood reference intervals and the influence of age and gender on hematologic and biochemical parameters of Santa Ines sheep bred in the eastern Amazon. Acta Amaz. 45(3):317-322. <http://dx.doi.org/10.1590/1809-4392201402115>

Peternelli Silva L. 2012. Avaliação clínica pelo escore de apgar modificado, concentração de lactato e glicemia em neonatos da espécie ovina. Dissertação de Mestrado, Universidade Estadual Paulista, Botucatu. 120p.

Piccione G., Costa A., Bertolucci C., Borruso M., Pennisi P. \& Caola G. 2006. Acid-base balance modifications in the lamb and goat kids during the first week of life. Small Rumin. Res. 63(3):304-308. <http://dx.doi.org/10.1016/j. smallrumres.2005.02.022>

Ravary-Plumioen B. 2009. Resuscitation procedures and life support of the newborn calf. Revue Méd. Vét. 160(8/9):410-419.

Regazzi F.M. 2015. Efeito da corticoterapia materna antenatal e pós-natal em cordeiros prematuros extremos. Dissertação de Mestrado, Universidade de São Paulo, São Paulo. 93p.

Rocha T.G., Franciosi C., Nociti R.P., Jorge R.L.N. \& Fagliari J.J. 2009. Concentrações séricas de cálcio, fósforo, magnésio, ferro e potássio em bezerros mestiços Canchim-Nelore e da raça Holandesa do nascimento aos 30 dias de idade. VIII Congresso Brasileiro de Buiatria, Belo Horizonte, MG, p.214-219.

Rodrigues J.A., Veiga G.A.L., Silva L.C., Lúcio C.F. \& Vannuchi C.I. 2007. Avaliação por escore APGAR, temperatura e hemogasometria arterial em neonatos da espécie ovina. Anais do XVII Congresso Brasileiro de Reprodução Animal, Curitiba, PR, p.23.

Ronco R. 2005. Blood lactate as prognostic marker in critically ill children. J. Pediatr. 81(4):271-272.<http://dx.doi.org/10.2223/1359><PMid:16106308>

Schoenau L.S.F., Pinto L.M., Pereira F.T.V., Schoenau W. \& Miglino M.A. 2005. Aspectos anatômicos de macro e microvascularização da placenta de ovinos (Ovis Aries). Braz. J. Vet. Res. Anim. Sci. 42(6):405-413. <http:// dx.doi.org/10.11606/issn.1678-4456.bjvras.2005.26398>

Silva L.C.G. 2012. Aplicação preventiva do surfactante porcino (Instituto Butantan ${ }^{\circledR}$ ) intra-traqueal no desempenho clínico e pulmonar de neonatos ovinos prematuros. Tese de Doutorado, Universidade de São Paulo, São Paulo 130p. <http://dx.doi.org/10.11606/T.10.2012.tde-05102012-161738>. 
Silva L.P., Lourenço M.L.G., Grandi M.C., Vela Ulian C.M., Sudano M.J. \& Chiacchio S.B. 2013. Concentração de lactato sérico em ovelhas e cordeiros mestiços (1/2 Suffolk) nascidos em eutocia. Arq. Bras. Med. Vet. Zootec. 65(4):989994. <http://dx.doi.org/10.1590/S0102-09352013000400008>

Silverman S.C. \& Birks E.K. 2002. Evaluation of the i-STAT hand-held chemical analyser during treadmill and endurance exercise. Equine Vet. J. 34(34):551554. <PMid:12405749>

Sparks J.W., Hay Junior W.W., Meschia G. \& Battaglia F.C. 1983. Partition of maternal nutrients to the placenta and fetus in sheep. Eur. J. Obstet. Gynecol. Reprod. Biol. 14(5):331-340. <http://dx.doi.org/10.1016/00282243(83)90009-6> <PMid:6840385>
Teixeira A., Rocha G. \& Guimarães H. 2007. Transição fetal neonatal no recémnascido de muito baixo peso. Acta Pediatr. Port. 36:250-256.

Vaala W.E. \& House J.K. 2006. Adaptação, asfixia e reanimação perinatais, p.266-276. In: Smith B.P. (Eds), Medicina interna de grandes animais. $3^{\text {a }}$ ed. Manole, São Paulo.

Vannucchi C.I., Rodrigues J.A., Silva L.C.G., Lúcio C.F. \& Veiga G.A.L. 2012. A clinical and hemogasometric survey of neonatal lambs. Small Rumin. Res. 108(1/3):107-112.<http://dx.doi.org/10.1016/j.smallrumres.2012.05.013>

Veronesi M.C., Gloria A., Panzani S., Sfirro M.P., Carluccio A. \& Contri A. 2014. Blood analysis in newborn donkeys: hematology, biochemistry and blood gases analysis. Theriogenology 82(2):294-303. http://dx.doi.org/10.1016/j. theriogenology.2014.04.004. PMID: 24831574. 